\title{
PENGEMBANGAN BUKU PENGAYAAN BERBASIS PAPPASENG SUKU BUGIS DALAM PEMBELAJARAN CERPEN DI SMA
}

\author{
THE DEVELOPMENT OF ENRICHMENT BOOK BASED ON \\ PAPPASENG OF BUGIS TRIBE IN SHORT STORY LEARNING AT \\ SENIOR HIGH SCHOOL
}

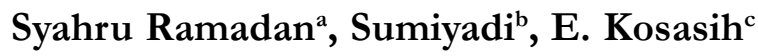 \\ ${ }^{a}$ Institut Agama Islam Negeri Bone \\ ${ }^{\mathrm{b}}$ Universitas Pendidikan Indonesia \\ 'Universitas Pendidikan Indonesia \\ Pos-el: syahru.ramadan.unm@upi.edu
}

\begin{abstract}
The purpose of this research is to develop teaching material in the form of a knowledge enrichment book based on pappaseng of Bugis tribe. The results of the development are then tested by experts, practitioners, and students. This research is research and development (R\&D) using adaptation of Hannafin and Peck's models. This model consists of three stages, namely requirements analysis, product design, and development and implementation. The results of this study indicate that the developed book product is suitable for use in learning. The eligibility based on the results of due diligence by experts and practitioners, as well as the results of field tests by students. Based on the assessment by experts and practitioners, it was found that the feasibility aspect of the book content/ material component obtained an average score of $92.3 \%$ with excellent criteria. In the aspect of the feasibility of the linguistic component an average score of 93.3\% was obtained with very good criteria. In the aspect of feasibility the presentation component obtained an average score of $87.2 \%$ with good criteria. In the aspect of eligibility the graphic component obtained an average score of $83.5 \%$ with good criteria. In the aspect of feasibility the usefulness component is obtained an average score of $88 \%$ with good criteria. After expert assessment, field tests are also conducted on students with the following results. (1) In the aspect of content/material obtained an average score of $88.08 \%$ with good criteria. (2) In linguistic aspects an average score of $89.52 \%$ is obtained with good criteria. (3) In the aspect of material presentation, an average score of $87.79 \%$ is obtained with good criteria. (4) In the aspect of graphic obtained an average score of $86.92 \%$ with good criteria. (5) In the aspect of usefulness an average score of $91.23 \%$ is obtained with very good criteria.
\end{abstract}

Keywords: teaching materials, enrichment book, short story, pappaseng

\begin{abstract}
Abstrak
Tujuan penelitian ini adalah mengembangkan bahan ajar berupa buku pengayaan pengetahuan berbasis pappaseng suku Bugis. Hasil pengembangan tersebut kemudian diuji oleh ahli, praktisi, dan peserta didik. Penelitian ini termasuk penelitian dan pengembangan dengan menggunakan adaptasi model Hannafin dan Peck. Model ini terdiri atas tiga tahap, yaitu analisis kebutuhan, desain produk, dan pengembangan dan implementasi. Hasil penelitian ini menunjukkan bahwa produk buku yang dikembangkan layak digunakan dalam pembelajaran. Kelayakan tersebut didasarkan atas hasil uji oleh ahli, praktisi, dan peserta didik. Berdasarkan penilaian oleh ahli dan praktisi, diperoleh hasil bahwa aspek kelayakan komponen isi/materi buku mendapatkan rata-rata skor $92,3 \%$ dengan kriteria sangat baik. Pada aspek kelayakan komponen kebahasaan diperoleh rata-rata skor 93,3\% dengan kriteria sangat baik. Pada aspek kelayakan komponen penyajian diperoleh rata-rata skor $87,2 \%$ dengan kriteria baik. Pada aspek kelayakan komponen kegrafikaan diperoleh rata-rata skor 83,5\% dengan kriteria
\end{abstract}


baik. Pada aspek kelayakan komponen kebermanfaatan diperoleh rata-rata skor $88 \%$ dengan kriteria baik. Setelah penilaian ahli, dilakukan pula uji lapangan pada peserta didik dengan hasil sebagai berikut. (1) Pada aspek isi/materi diperoleh rata-rata skor 88,08\% dengan kriteria baik. (2) Pada aspek kebahasaan diperoleh rata-rata skor $89,52 \%$ dengan kriteria baik. (3) Pada aspek penyajian materi diperoleh ratarata skor $87,79 \%$ dengan kriteria baik. (4) Pada aspek kegrafikaan diperoleh rata-rata skor $86,92 \%$ dengan kriteria baik. (5) Pada aspek kebermanfaatan diperoleh rata-rata skor 91,23\% dengan kriteria sangat baik.

Kata kunci: bahan ajar, buku pengayaan, cerpen, pappaseng

\section{PENDAHULUAN}

Pembelajaran bahasa dan sastra Indonesia dalam Kurikulum 2013 adalah pembelajaran berbasis teks. Pembelajaran teks yang dimaksud tidak hanya terbatas pada pengetahuan teoretis terhadap segala unsur kebahasaan suatu teks, tetapi juga memerhatikan efek komunikasi dan dampak fungsi sosial dari teks tersebut. Artinya, pembelajaran teks mengedepankan peserta didik untuk mampu menggunakan berbagai jenis teks dalam kehidupan masyarakat. Hal itu sejalan dengan pendekatan pembelajaran bahasa di Eropa dan Amerika yang menggunakan pendekatan CLIL (Content Language Integrated Learning) yang menonjolkan empat unsur penting, yaitu isi, bahasa atau komunikasi, kognisi, dan budaya (Kemdikbud, 2017: iii).

Pembelajaran bahasa dan sastra Indonesia, seperti pada pembelajaran bidang studi lainnya, menggunakan buku sebagai bahan ajar utama. Buku merupakan media yang dapat membuat, menyajikan berbagai informasi dan berbagai keperluan, serta mengomunikasikan nilai-nilai sosial budaya, baik langsung maupun tidak langsung (Sitepu, 2015; Normawati, 2015).

Pemerintah telah membantu menyediakan buku sebagai sumber bahan ajar bagi guru dan peserta didik, yaitu buku teks bagi guru dan peserta didik. Namun, dalam perkembangannya, bahan ajar berupa buku teks bahasa Indonesia tersebut memiliki keterbatasan dalam mendukung proses pembelajaran.
Berdasarkan hasil observasi pada beberapa SMA di Bone, diperoleh beberapa informasi, yaitu guru memiliki keterbatasan dalam memanfaatkan bahan ajar. Mereka masih mengandalkan bahan ajar berupa buku teks yang disediakan oleh pemerintah tanpa mengembangkan bahan ajar sendiri yang kreatif, inovatif, dan mampu mendorong semangat belajar peserta didik. Selain itu, kebudayaan lokal yang bersifat kontekstual sangat sedikit tergambar dalam buku teks yang digunakan, khususnya kebudayaan Bugis. Kebudayaan yang dipaparkan dalam buku teks tersebut lebih banyak yang bersifat populer. Akibatnya, peserta didik akan cenderung mengetahui kebudayaan populer daripada kebudayaan lokalnya. Hal itu akan berdampak pada memudarnya pengetahuan dan pemahaman kepada kebudayaan lokal. Hal itu sejalan dengan penelitian Subair (2017) yang menemukan bahwa kebudayaan lokal Bugis telah banyak dilupakan oleh generasi muda. Contohnya pada ungkapan tabek yang masih digunakan, tidak lagi disertai dengan menundukkan badan dan pandangan. Terkadang, seorang terkesan meneriakkannya atau malah terkesan menantang dengan tatapan yang jelalatan dan badan yang tidak lagi dibungkukkan. Bahkan, ada yang mengucapkannya sambil berjalan tergesa-gesa, setengah berlari atau berlari, dan menabrak orang yang diberi tabek.

Dari sisi peserta didik, mereka cenderung kurang semangat dalam belajar bahasa dan sastra Indonesia, terutama dalam pembelajaran cerpen. Mereka kebingungan ketika menentukan topik 
yang akan dijadikan sebuah cerpen. Contoh-contoh cerpen yang dihadirkan dalam buku teks tidak kontekstual dan jauh dari kehidupan sehari-hari mereka. Hal itu membuat peserta didik terbatas dalam mengekplorasi segala ide yang berkaitan dengan kehidupan sekitar dan kebudayaan mereka.

Di sisi lain, pemerintah saat ini sangat gencar melakukan pembelajaran berbasis pendidikan karakter. Pendidikan karakter sendiri sangat banyak dimuat dalam kebudayaan-kebudayaan lokal mayarakat, tidak terkecuali pada kebudayaan Bugis. Oleh karena itu ada baiknya jika pembelajaran bahasa Indonesia, salah satunya cerpen, dapat mengintegrasikan kebudayaan-kebudayaan lokal agar kebudayaan lokal senantiasa diingat dan diaplikasikan oleh peserta didik. Selain itu, mereka juga dapat memperoleh nilai-nilai karakter dari kebudayaan tersebut.

Salah satu wujud kebudayaan masyarakat Bugis adalah pappaseng. Kebudayaan tersebut secara harfiah berasal dari kata paseng yang berarti kumpulan pesan atau petunjuk (Pelras, 2006: 248). Sikki, dkk. (1998: 6) mengungkapkan bahwa makna pappaseng sesungguhnya sama dengan kata wasiat, karena sifatnya yang mengikat dan patut diikuti. Pappaseng hadir di tengah masyarakat Bugis sebagai media pendidikan moral. Hal itu sejalan dengan hasil penelitian Ramadan, dkk. (2018) yang menemukan bahwa di dalam pappaseng dimuat beragam nilai-nilai karakter yang dapat diaplikasikan oleh masyarakat dalam kehidupan sehari-hari.

Berangkat dari permasalahan-permasalahan tersebut, maka dianggap perlu membuat dan mengembangkan bahan ajar tentang cerpen berbasis kebudayaan Bugis, yaitu pappaseng. Bahan ajar yang dikembangkan berwujud buku pengayaan pengetahuan. Buku pengayaan merupakan buku tambahan yang bertujuan memperkaya wawasan, pengalaman, dan pengetahuan peserta didik, serta membentuk kepribadian peserta didik, pendidik, pengelola pendidikan, dan masyarakat lainnya (Suherli, 2008). Rencana untuk merancang produk pengembangan buku pengayaan juga mendapat respons yang baik dari guru dan peserta didik yang diobservasi. Dengan demikian, maka peneliti akan melakukan penelitian berupa pengembangan produk berupa buku pengayaan cerpen berbasis pappaseng suku Bugis.

\section{KERANGKA TEORI}

\section{Cerpen}

Cerita pendek merupakan cerita rangkaian peristiwa yang saling terkait dan di dalamnya terjadi konflik antartokoh atau dalam diri tokoh dalam latar dan alur (Sutardi, 2012: 59). Sesuai dengan namanya, cerita pendek atau short story adalah jenis cerita yang terdiri atas sejumlah halaman, mulai lima sampai dengan dua puluh halaman dan dapat dibaca sekali duduk sekitar setengah sampai dua jam (Jassin, 1965: 64; Nurgiyantoro, 2013: 12; Ratna, 2013: 88). Cerpen menyajikan sebagian kecil kehidupan manusia, tetapi dikemas sedemikian rupa sehingga tetap memberikan pemahaman yang menyeluruh mengenai makna kehidupan tersebut. Aminuddin (2014: 66) mendefinisikan cerpen sebagai kisahan atau cerita yang diemban oleh pelaku-pelaku tertentu dengan pemeranan, latar serta tahapan dan rangkaian cerita tertentu yang bertolak dari hasil imajinasi pengarangnya sehingga menghasilkan suatu cerita. Unsur-unsur intrinsik dalam suatu cerpen harus terjalin satu sama lain.

Dari beberapa pandangan para ahli di atas, dapat disimpulkan bahwa cerita pendek atau cerpen merupakan salah satu jenis karya sastra berbentuk prosa yang memaparkan kisah atau cerita tentang kehidupan manusia, serta diperankan oleh tokoh-tokoh imajiner atau faktual dan ditulis berdasarkan perenungan, penghayatan, dan 
penjiwaan dari pengarang sehingga menghasilkan nilai-nilai yang bermakna. Jumlah halaman tidak menjadi titik fokus dalam cerpen, tetapi yang menjadi titik fokusnya adalah kesan tunggal dalam cerita.

Cerita pendek atau cerpen, layaknya karya prosa lain, memiliki unsur-unsur dan struktur pembangun. Unsur-unsur pembangun cerpen terdiri atas unsur intrinsik dan ekstrinsik. Hal itu sejalan dengan pandangan Wellek \& Warren (2016) yang mengungkapkan bahwa terdapat dua tahap kajian dalam sastra, yaitu kajian intrinsik dan ekstrinsik. Kajian intrinsik menelaah sebuah karya sastra secara batiniah atau dari sisi dalam, lalu kajian ekstrinsik menelaah sebuah karya sastra secara lahiriah atau dari sisi luar.

Dalam penelitian ini, materi cerpen yang dimasukkan disesuaikan dengan kompetensi yang harus dicapai oleh peserta didik. Dalam buku pengayaan yang dikembangkan, materi cerpen dimasukkan ke dalam BAB II dengan mengintegrasikan antara cerpen dan pappaseng suku Bugis.

\section{Pappaseng}

Pappaseng merupakan salah satu bentuk kearifan lokal suku Bugis yang secara harfiah berarti kumpulan pesan atau petunjuk (Pelras, 2006: 248). Sikki, dkk. (1998: 6) mengungkapkan bahwa makna pappaseng sesungguhnya sama dengan kata wasiat karena sifatnya yang mengikat dan patut diikuti. Pappaseng secara umum berisi petunjuk tentang cara menjalani kehidupan, baik dalam menjalani hubungan dengan sesama manusia maupun menjalani hubungan dengan Sang Pencipta (Sikki, dkk. 1998: 7).

Pappaseng pada awalnya disampaikan secara lisan. Cara tersebut dikenal dengan istilah maggaligo. Seiring perkembangan zaman, pappaseng kemudian dikumpulkan dalam bentuk naskah yang disebut lontaraq (Elfira, 2013: 22). Pappaseng hadir di tengah masyarakat Bugis sebagai media pen- didikan moral. Pappaseng bertujuan untuk membangun kualitas pribadi masyarakat yang ideal, yakni membawa manfaat pada alam semesta. Oleh karena itu, di dalam pappaseng akan sering ditemukan ajaran-ajaran tentang karakter mulia yang dalam pandangan peneliti dapat diserap dan diaktualisasikan dalam kehidupan sehari-hari.

Pappaseng yang hidup dalam masyarakat suku Bugis sangat banyak, terdiri atas ratusan bahkan ribuan. Cara pengungkapan atau penuturannya pun dapat dilakukan dalam bermacam-macam bentuk, misalnya dalam bentuk elong 'puisi', werekkada 'peribahasa', dan percakapan 'monolog dan dialog'. Selain itu, wujud pappaseng dapat menggunakan bahasa denotatif dan konotatif atau figuratif.

Pappaseng umumnya diungkapkan oleh orangorang tua kepada generasi muda untuk memberikan nasihat dalam mengarungi roda kehidupan. Biasanya, dalam hal-hal tertentu pembicara menyelipkan pappaseng dalam mengungkapkan sesuatu sehingga menjadi menarik dan pendengar menjadi lebih serius dalam mendengar dan menyimak pembicaraan. Akan tetapi, dewasa ini, khususnya di daerah perkotaan, sudah jarang orang-orang tua memberikan nasihat kepada generasi muda dengan menggunakan pappaseng. Bahkan, beberapa orang tua sudah ada yang tidak mengenal ada pappaseng lagi. Hal inilah yang menjadi kekhawatiran bagi peneliti sehingga peneliti akan memperkenalkan kembali pappaseng dalam bentuk yang lebih menarik kepada generasi muda dengan tujuan mereka dapat mengaktualisasikan nilai-nilai dalam pappaseng tersebut dalam kehidupan sehari-hari.

Dalam buku pengayaan yang dikembangkan, materi pappaseng ditempatkan pada BAB I. Hal itu dilakukan untuk memperlihatkan dan memperkenalkan kepada peserta didik salah satu bentuk kebudayaan suku Bugis. 


\section{Buku Pengayaan}

Buku pengayaan merupakan buku pembelajaran selain buku teks yang digunakan dalam pembelajaran dan dianjurkan bagi peserta didik untuk membacanya guna menambah pengetahuan dan wawasan (Pusat Perbukuan Depdiknas dalam Suherli, 2008). Lebih jauh, Suherli (2008) mengungkapkan bahwa buku pengayaan dimaksudkan untuk (1) memperkaya wawasan, pengalaman, dan pengetahuan peserta didik; dan (2) membentuk kepribadian peserta didik, pendidik, pengelola pendidikan, dan masyarakat lainnya.

Buku pengayaan memiliki beberapa jenis. Jenis-jenis tersebut didasarkan atas dominasi materi atau isi yang disajikan di dalamnya. Jenisjenis buku pengayaan adalah buku pengayaan pengetahuan, keterampilan, dan kepribadian. Buku pengayaan pengetahuan adalah buku yang memuat materi yang dapat memperkaya penguasaan ilmu pengetahuan, teknologi, seni, dan menambah kekayaan wawasan akademik pembacanya. Buku pengayaan keterampilan adalah buku yang memuat materi yang dapat memperkaya penguasaan keterampilan bidang tertentu. Buku pengayaan kepribadian adalah buku yang memuat materi yang dapat memperkaya kepribadian atau pengalaman batin seseorang.

Berdasarkan dominasi isi buku pengayaan yang dikembangkan, buku tersebut tergolong ke dalam buku pengayaan pengetahuan yang dapat memperkaya pengetahuan peserta didik mengenai pappaseng dan hasil integrasinya dengan cerpen.

\section{METODE}

Penelitian ini merupakan penelitian dan pengembangan atau Research and Development (R\&D). Penelitian dan pengembangan bertujuan untuk meneliti, mengembangkan, dan menguji suatu produk. Hal itu sejalan dengan pandangan Sugiyono (2016: 29) bahwa penelitian dan pengembangan merupakan kajian sistematis mengenai bagaimana membuat rancangan suatu produk, mengembangkan rancangan produk, dan mengevaluasi kinerja produk tersebut dengan tujuan memperoleh data empiris sebagai landasan untuk menjadikan produk tersebut dapat digunakan dalam proses pembelajaran atau nonpembelajaran. Penelitian ini mengembangkan produk berupa buku pengayaan pengetahuan tentang cerpen berbasis pappaseng suku Bugis.

Adapun model R\&D yang digunakan adalah model Hannafin dan Peck (1988: 60) yang telah diadaptasi dan disesuaikan dengan kebutuhan penelitian. Model ini mencakup tiga tahap, yaitu (1) tahap penilaian kebutuhan (need assesment), (2) tahap perancangan (design), dan (3) tahap pengembangan dan implementasi (development and implementation). Model ini dipilih karena memang berorientasi pada penghasilan produk (Kartikasari, dkk. 2016: 57).

Data dalam penelitian ini, yaitu: (1) hasil transkripsi dan pencatatan pappaseng suku Bugis, serta tuturan lisan masyarakat Bugis Bone yang berisi pappaseng; (2) skor angket kebutuhan pengembangan buku pengayaan dari persepsi guru dan peserta didik SMAN 18 Bone dan MAN 1 Bone; (3) angket hasil uji kelayakan produk buku pengayaan oleh ahli dan praktisi; serta (4) angket hasil uji coba lapangan oleh peserta didik kelas XI SMA di SMAN 18 Bone dan MAN 1 Bone. Kemudian, sumber data dalam penelitian ini disesuaikan dengan data penelitian, yaitu (1) buku hasil transkripsi pappaseng yang telah diterbitkan; (2) masyarakat Bugis yang memiliki pemahaman dan sering menuturkan pappaseng; (3) dosen ahli dan praktisi; serta (4) peserta didik.

Instrumen dalam penelitian ini berupa angket. Teknik analisis data dalam penelitian ini menggunakan pedoman penilaian dari Arikunto (2006: 216) yang menyatakan bahwa untuk mengetahui peringkat nilai akhir untuk butir pernyataan dalam 
intrumen, jumlah nilai harus dibagi dengan banyaknya responden yang menjawab angka tersebut. Dari perhitungan tersebut diperoleh hasil bahwa produk yang dikembangkan dapat dinyatakan layak jika hasil rata-rata skor mendapat kriteria baik atau sangat baik, yaitu lebih dari 75\% sehingga tidak perlu direvisi.

\section{HASIL DAN PEMBAHASAN}

Bahan ajar berupa buku pengayaan cerpen berbasis pappaseng suku Bugis dikembangkan dengan menggunakan model Hannafin dan Peck. Model tersebut memiliki tiga tahapan, yaitu (1) tahap penilaian kebutuhan (need assesment), (2) tahap perancangan (design), serta (3) tahap pengembangan dan implementasi (development and implementation). Ketiga tahapan tersebut akan dijelaskan pada bagian berikut.

\section{Tahap Penilaian Kebutuhan}

Tahap ini dilakukan untuk mengetahui kondisi lapangan. Kondisi tersebut meliputi proses dan permasalahan dalam pembelajaran bahasa Indonesia. Hal tersebut akan menjadi acuan untuk melakukan pengembangan produk berupa buku pengayaan. Hal yang dilakukan dalam tahap ini adalah observasi pembelajaran, observasi bahan ajar, wawancara dengan guru, dan penyebaran angket pada peserta didik. Observasi tersebut dilakukan di SMAN 18 Bone dan MAN 1 Bone.

Dari kegiatan observasi dan wawancara yang dilakukan di dua tempat tersebut, diperoleh beberapa informasi, antara lain: (1) Proses pembelajaran berlangsung cukup monoton. Guru masih mendominasi pembelajaran. Hal itu membuat peserta didik merasa bosan dan kurang bergairah. (2) Berkaitan dengan bahan ajar, guru masih mengandalkan buku teks pelajaran yang disediakan oleh pemerintah. Guru belum berupaya mengembangkan bahan ajar lain yang dapat memotivasi dan mendorong peserta didik aktif dalam pembelajaran. (3) Dari hasil wawancara, guru memiliki keterbatasan dalam memanfaatkan bahan ajar. Mereka membutuhkan tambahan bahan ajar. Salah satu bentuk bahan ajar itu adalah buku pengayaan yang dapat membantu dan mendorong tercapainya tujuan pembelajaran yang telah ditetapkan. (4) Dari hasil pembagian angket ke peserta didik, mereka membutuhkan bahan ajar alternatif yang bersifat kontekstual.

\section{Tahap Perancangan}

Setelah analisis kebutuhan dilakukan, tahap selanjutnya yang diperbuat adalah perancangan bahan ajar berupa buku pengayaan cerpen berbasis pappaseng suku Bugis. Perancangan tersebut didasarkan atas studi pendahuluan dan hasil analisis kebutuhan. Perancangan disesuaikan dengan langkah kedua model Hannafin dan Peck, yaitu design. Berikut ini diuraikan tahap perancangan buku pengayaan cerpen berbasis pappaseng suku Bugis.

Pertama, melakukan identifikasi tujuan pembelajaran. Identifikasi tujuan pembelajaran berkaitan dengan kompetensi yang harus dicapai oleh peserta didik dalam pembelajaran. Kompetensi dan tujuan pembelajaran mengacu pada Kurikulum 2013 Edisi Revisi 2017. Buku pengayaan yang dikembangkan dapat membantu peserta didik dalam mencapai kompetensi dan tujuan yang telah ditetapkan.

Kedua, melakukan analisis pembelajaran. Analisis tersebut bertujuan untuk mengidentifikasi materi yang harus dipelajari oleh peserta didik, yaitu materi cerpen. Dalam materi tersebut diperoleh informasi bahwa cakupan kompetensi pembelajaran adalah aspek spritual, sosial, pengetahuan, dan keterampilan. Keempat kompetensi tersebut diintegrasikan dalam proses pembelajaran dengan menggunakan buku pengayaan pengetahuan yang dikembangkan dalam penelitian ini. Cakupan materi cerpen yang disajikan dalam buku 
pengayaan pengetahuan ini meliputi hakikat cerpen, unsur dan struktur cerpen, kaidah cerpen, teknik-teknik memulai menulis cerpen, dan kumpulan beberapa cerpen berbasis pappaseng.

Ketiga, membuat rancangan format buku pengayaan. Rancangan tersebut disesuaikan dengan analisis kebutuhan. Pengembangan buku pengayaan mengacu pada prinsip-prinsip dasar dalam membuat rancangan buku yang disampaikan Sitepu (2015: 127-160), yaitu (1) memerhatikan ukuran buku; (2) ukuran huruf dan spasi baris; (3) jenis huruf; (4) spasi dan susunan; (5) teknik menulis teks; (6) ilustrasi; dan (7) anatomi buku teks pelajaran.

Pusat Perbukuan Depdiknas (2008: 66) mengungkapkan terdapat tiga bagian umum dalam sebuah buku, yaitu bagian awal, bagian isi, dan bagian akhir. Bagian awal minimal terdiri atas kata pengantar atau prakata dan daftar isi. Bagian isi memuat materi buku. Bagian akhir memuat daftar pustaka dan dapat disertai dengan glosarium, indeks, dan lampiran. Seorang penulis buku nonteks (pengayaan) harus memerhatikan ketiga bagian buku tersebut ketika hendak menyusun atau mengembangkan buku.

Buku yang dikembangkan berupa buku pengayaan pengetahuan yang dapat memperkaya penguasaan ilmu pengetahuan, teknologi, seni, dan menambah kekayaan wawasan akademik pembacanya. Walaupun buku yang dikembangkan berupa buku pengayaan pengetahuan, di dalam buku juga dijumpai teknik-teknik dalam memulai menulis cerpen yang bertujuan memberikan keterampilan bagi pembaca sehingga tampak seperti buku keterampilan. Kemudian, di dalam buku juga dijumpai contoh-contoh cerpen yang memuat banyak nilai kehidupan. Hal tersebut bertujuan untuk menanamkan dan membentuk karakter yang baik pada diri pembaca sehingga akan tampak seperti buku pengayaan kepribadian.
Rancangan visual atau tata letak buku berpedoman pada standar evaluasi bahan ajar yang dibuat oleh Pusat Perbukuan Depdiknas (2008: 67) yang memuat empat komponen, yaitu kelayakan isi, kebahasaan, penyajian, dan kegrafikan, kemudian dimodifikasi sesuai kepentingan penelitian dengan menambahkan komponen manfaat.

\section{Tahap Pengembangan dan Implementasi}

Dalam tahap pengembangan dan implementasi diuraikan proses pengembangan dan implementasi buku pengayaan pengetahuan. Hal tersebut berupa evaluasi produk oleh para ahli dan praktisi, yang mencakup dosen ahli pembelajaran dan sastra, guru bahasa Indonesia, penerbit, dan peserta didik. Dalam tahap ini dideskripsikan empat hal, yaitu (1) validasi ahli dan praktisi, (2) revisi hasil validasi buku, (3) uji coba buku, dan (4) produk akhir buku. Berikut penjelasan keempat poin tersebut secara jelas.

\section{Validasi Ahli dan Praktisi}

Buku pengayaan pengetahuan yang dikembangkan ini dinilai dan diuji kelayakannya oleh enam orang ahli dan praktisi. Pemilihan ahli dan praktisi didasarkan atas beberapa kriteria, antara lain: (1) memiliki kualifikasi akademik minimal Magister Pendidikan Bahasa Indonesia atau Magister Humaniora Sastra Indonesia untuk ahli bahan ajar; (2) memiliki pengalaman mengajar lebih dari sepuluh tahun untuk praktisi pembelajaran; dan (3) menguasai bidang kegrafikaan minimal dipelajari sampai tingkat sarjana untuk ahli kegrafikaan. Berdasarkan kriteria tersebut dipilihlah enam orang yang terdiri atas ahli dan praktisi, yaitu (1) Dr. E. Kosasih, M.Pd. (Dosen Pendidikan Bahasa Indonesia Universitas Pendidikan Indonesia), (2) Dr. Syamsudduha, M.Hum. (Dosen Pendidikan Bahasa dan Sastra Indonesia/ Daerah Universitas Negeri Makassar), (3) Sultan, S.Pd. (Guru Bahasa Indonesia SMAN 18 Bone, 
(4) H. Beddu Solong, S.Pd. (Guru Bahasa Indonesia MAN 1 Bone), (5) Muhammad Arfan, S.Ds (Penerbit Syahadah Bone), dan (6) Randi Saputra, S.Ds (Penerbit Erlangga Cabang Bone).

Ahli dan praktisi menilai kelayakan buku dari beberapa komponen, antara lain komponen isi/ materi, komponen kebahasaan, komponen penyajian materi, komponen kegrafikaan, dan komponen kebermanfaatan. Tahapan awal penilaian dilakukan oleh tiga orang ahli dan praktisi, yaitu Dr. E. Kosasih, M.Pd., Sultan, S.Pd., dan Muhammad Arfan, S.Ds. Hasil penilaian ketiga ahli dan prkatisi sebagai berikut.

Pada aspek kelayakan komponen isi/materi diperoleh rata-rata skor $81 \%$ dengan kriteria baik. Pada aspek kelayakan komponen kebahasaan diperoleh rata-rata skor 78,3\% dengan kriteria baik. Pada aspek kelayakan komponen penyajian diperoleh rata-rata skor $82,2 \%$ dengan kriteria baik. Pada aspek kelayakan komponen kegrafikaan diperoleh rata-rata skor $73,9 \%$ dengan kriteria baik. Pada aspek kelayakan komponen kebermanfaatan diperoleh rata-rata skor $84,7 \%$ dengan kriteria baik.

Walaupun rata-rata skor yang diperoleh berada pada kriteria baik, tetapi terdapat beberapa catatan dari penilai untuk memperbaiki kualitas buku pengayaan yang dikembangkan. Secara lebih jelas, catatan para ahli dan praktisi akan dibahas pada bagian selanjutnya.

\section{Revisi Hasil Validasi Buku}

Hasil penilaian validator menunjukkan bahwa komponen-komponen buku pengayaan pengetahuan yang dikembangkan memiliki kriteria baik. Akan tetapi, terdapat beberapa bagian yang harus direvisi, khususnya pada aspek kegrafikaan (desain sampul buku) dan komponen isi (keakuratan materi). Berdasarkan beberapa komentar dan saran yang diberikan oleh validator, buku pengayaan pengetahun cerpen berbasis pappaseng suku Bugis kemudian direvisi. Setelah itu, dilakukan lagi uji kelayakan tahap dua oleh tiga ahli dan praktisi lainnya, yaitu Dr. Syamsudduha, M.Hum., H. Beddu Solong, S.Pd., dan Randi Saputra, S.Ds. Hasil penilaian tahap dua ini diuraikan sebagai berikut.

Pada aspek kelayakan komponen isi/materi diperoleh rata-rata skor 92,3\% dengan kriteria sangat baik. Pada aspek kelayakan komponen kebahasaan diperoleh rata-rata skor 93,3\% dengan kriteria sangat baik. Pada aspek kelayakan komponen penyajian diperoleh rata-rata skor $87,2 \%$ dengan kriteria baik. Pada aspek kelayakan komponen kegrafikaan diperoleh rata-rata skor 83,5\% dengan kriteria baik. Pada aspek kelayakan komponen kebermanfaatan diperoleh rata-rata skor 88\% dengan kriteria baik.

Semua validator pada validasi tahap dua menganggap bahwa buku pengayaan yang dikembangkan sudah layak digunakan kepada peserta didik. Selanjutnya, dilakukan uji coba lapangan kepada peserta didik di dua sekolah, yaitu SMAN 18 Bone dan MAN 1 Bone.

\section{Uji Coba Buku}

Uji coba lapangan dilakukan pada dua kelompok peserta didik Kelas XI, yaitu dari SMAN 18 Bone dan MAN 1 Bone. Setiap sekolah diujicobakan pada satu kelas. Uji coba lapangan ini melibatkan 65 peserta didik, yaitu 30 orang dari Kelas XI MIA 1 SMAN 18 Bone dan 35 orang dari Kelas XI MIA 1 MAN 1 Bone. Dalam tahap uji coba lapangan ini, dilakukan penyebaran angket berupa tanggapan peserta didik atas buku pengayaan pengetahuan cerpen berbasis pappaseng suku Bugis. Angket berupa tanggapan atau respons peserta didik memuat beberapa aspek, antara lain: (1) aspek isi/materi, (2) kebahasaan, (3) penyajian, (4) kegrafikaan, dan (5) kebermanfaatan.

Uji coba lapangan yang dilakukan pada 65 peserta didik dari Kelas XI MIA 1 SMAN 18 Bone 
dan Kelas XI MIA 1 MAN 1 Bone menghasilkan perolehan nilai sebagai berikut. (1) Pada aspek isi/ materi diperoleh rata-rata skor 88,08\% dengan kriteria baik. (2) Pada aspek kebahasaan diperoleh rata-rata skor 89,52\% dengan kriteria baik. (3) Pada aspek penyajian materi diperoleh rata-rata skor $87,79 \%$ dengan kriteria baik. (4) Pada aspek kegrafikaan diperoleh rata-rata skor $86,92 \%$ dengan kriteria baik. (5) Pada aspek kebermanfaatan diperoleh rata-rata skor 91,23\% dengan kriteria sangat baik.

Berdasarkan hasil uji coba lapangan dengan memberikan angket tanggapan atau respons peserta didik, bahan ajar berupa buku pengayaan pengetahuan cerpen berbasis pappaseng suku Bugis untuk Kelas XI SMA dinyatakan telah layak digunakan sebagai penunjang dalam proses pembelajaran bahasa Indonesia.

\section{Produk Akhir Buku}

Setelah melalui berbagai jenis uji kelayakan, mulai dari uji validasi ahli dan praktisi, sampai pada uji lapangan, diperoleh hasil bahwa buku pengayaan pengetahuan cerpen berbasis pappaseng suku Bugis layak digunakan dalam proses pembelajaran bahasa Indonesia Kelas XI. Produk akhir buku pengayaan pengetahuan ini memiliki ketebalan 104 halaman ditambah dengan vi halaman.

\section{Pembahasan}

Produk buku yang dikembangkan telah melalui uji kelayakan, baik dari dosen ahli, guru bahasa Indonesia, penerbit buku, maupun peserta didik. Hasil uji kelayakan tersebut menyatakan bahwa produk buku pengayaan cerpen berbasis pappaseng suku Bugis layak digunakan sebagai bahan ajar pendamping dalam proses pembelajaran bahasa Indonesia di SMA.

Hasil akhir pengembangan buku pengayaan cerpen berbasis pappaseng suku Bugis ini memiliki beberapa keunggulan, antara lain: (1) menjadi pelopor buku-buku yang mengangkat dan mengintegrasikan kebudayaan suku Bugis dengan pembelajaran bahasa Indonesia; (2) memperkaya buku-buku pengayaan bahasa Indonesia; (3) menjadi upaya pengenalan kembali kebudayaan suku Bugis kepada generasi muda; dan (4) menumbuhkan kecintaan pembaca kepada kebudayaan daerah.

Keunggulan yang pertama berkaitan dengan menjadi pelopor buku-buku yang mengangkat dan mengintegrasikan kebudayaan suku Bugis dengan pembelajaran bahasa Indonesia. Produk yang dikembangkan dapat menjadi pelopor bagi kemunculan buku-buku yang mengangkat kebudayaan daerah, khususnya kebudayaan suku Bugis. Penelitian ini merupakan penelitian yang baru dalam hal pengembangan buku yang mengintegrasikan kebudayaan suku Bugis dengan pembelajaran bahasa Indonesia. Penelitian-penelitian sebelumnya mengenai kebudayaan Bugis, seperti penelitian Syamsudduha (2014) dan Andi Tenri Sua (2018) hanya mengungkapkan secara teoretis nilai-nilai karakter dalam tuturan pappaseng atau ungkapan Bugis tanpa mengembangkan lebih jauh pappaseng secara praktis sehingga dapat digunakan dalam proses pembelajaran. Hadirnya buku ini, maka dapat merangsang buku-buku yang sejenis untuk hadir juga. Makin banyaknya buku-buku yang mengangkat kebudayaan daerah dan diintegrasikan dalam pembelajaran dapat menambah dan memperkaya sumber pustaka bagi pembaca, khususnya peserta didik.

Keunggulan kedua berkaitan dengan memperkaya buku-buku pengayaan pada mata pelajaran bahasa Indonesia. Hal ini dapat berjalan dengan baik karena berdasarkan hasil observasi di beberapa sekolah dan perpustakaan sekolah di Kabupaten Bone, tidak ditemukan bahan ajar lain berupa buku pengayaan atau referensi yang dapat membantu proses pembelajaran. Buku pengayaan cerpen berbasis pappaseng suku Bugis nantinya 
dapat diperbanyak sehingga dapat digunakan oleh semua pihak, baik peserta didik maupun pembaca umum.

Keunggulan ketiga berkaitan dengan upaya pengenalan kembali kebudayaan suku Bugis kepada pembaca. Telah dipaparkan sebelumnya bahwa masyarakat Bugis, khususnya di Bone, banyak yang sudah tidak mengetahui kebudayaan daerahnya, termasuk pappaseng. Padahal, pappaseng sejak dahulu telah digunakan oleh orang-orang tua sebagai pedoman hidup. Bahkan, banyak nilai pendidikan karakter yang terdapat di dalamnya. Dengan hadirnya buku tersebut, maka kebudayaan suku Bugis dapat diperkenalkan kembali kepada pembaca, dalam hal ini generasi muda secara umum dan peserta didik secara khusus.

Keunggulan keempat berkaitan dengan menumbuhkan rasa cinta kepada kebudayaan daerah. Isi buku pengayaan cerpen berbasis pappaseng suku Bugis dikemas dengan menarik. Ilustrasi atau contoh cerpen dalam buku banyak dibumbui dengan pappaseng dan banyak menggambarkan lingkungan kebudayaan sekitar masyarakat Bugis Bone. Dengan manghadirkan hal-hal yang bersifat kontekstual atau dekat dengan pembaca, dapat membuat mereka mencintai kembali kebudayaan daerahnya.

\section{PENUTUP}

Buku pengayaan pengetahuan cerpen berbasis pappaseng suku Bugis yang dikembangkan dengan menggunakan model Hannafin dan Peck dinyatakan layak digunakan sebagai bahan ajar pendamping dalam pembelajaran bahasa Indonesia. Hasil tersebut membuat buku yang dikembangkan mendapat respons yang baik. Selain itu, buku tersebut juga direkomendasikan untuk dicetak dan disebarkan secara luas agar dapat digunakan dalam proses pembelajaran, khususnya di daerah Sulawesi Selatan.
Buku-buku tersebut dapat menjadi pelopor buku-buku yang mengangkat dan mengintegrasikan kebudayaan suku Bugis dengan pembelajaran bahasa Indonesia. Selain itu, dapat pula memperkaya buku-buku pengayaan pada mata pelajaran bahasa Indonesia, menjadi upaya mengenalkan kembali kebudayaan suku Bugis kepada pembaca, dan menumbuhkan rasa cinta pembaca kepada kebudayaan daerah.

\section{DAFTAR PUSTAKA}

Arikunto, S. 2006. Metode Penelitian: Prosedur Penelitian Suatu Pendekatan Praktik. Jakarta: Rineka Cipta.

Depdiknas. 2008. Pedoman Penilaian Buku Nonteks Pelajaran. Jakarta: Departemen Pendidikan Nasional.

Hannafin, M.J., \& Kyle, L.P. 1988. The Design, Development and Evaluation of Intruction Software. New York: Macmillan Publishing Company.

Istanti, W. 2016. "Pengembangan Buku Pengayaan Apresiasi Sastra Berhuruf Braille Indonesia dengan Media Reglet bagi Siswa Tunanetra di Sekolah Inklusi Kota Surakarta". Jurnal Indonesian Language Education and Literature, 2(1), 76--87.

Kartikasari, I., Rusdi, M., \&Asyhar, R. 2016. "Konstruksi dan Validasi Model Desain Pembelajaran Berbasis Masalah untuk Mengembangkan Kreativitas Siswa". Edu-Sains. Jurnal Pendidikan Matematika dan Ilmu Pengetabuan Alam Universitas Jember, 5(1), 56--68.

Kemdikbud. 2017. Bahasa Indonesia Edisi Revisi

(Buku Siswa). Jakarta: Pusat Kurikulum dan Perbukuan, Balitbang, Kemdikbud.

Normawati. 2015. "Nilai Pendidikan Karakter dalam Buku Teks Pelajaran Bahasa Indonesia SMA di Daerah Istimewa Yogyakarta". Jurnal Pendidikan Karakter, 5(1), 48--59. 
Pelras, C. 2006. Manusia Bugis (terjemahan The Bugis). Jakarta: Forum Jakarta-Paris Ecole francaise d'Extreme-Orient.

Sikki, dkk. 1998. Nilai dan Manfaat Pappaseng dalam Sastra Bugis. Jakarta: Pusat Pembinaan dan Pengembangan Bahasa.

Suherli. 2008. "Menulis Buku Pengayaan". [Online]. Diakses dari http:// suherlicentre.blogspot.co.id/2008/06/ menulis-buku-pengayaan.html.

Ramadan, S., Rengko, S., \& Kosasih, E. 2018. "Nilai-Nilai Pendidikan Karakter dalam Sastra Lisan Ada Pappaseng”. Seminar Internasional Riksa Bahasa, 769--778.

Septarianto, T. W. 2016. "Pengembangan Buku Pengayaan Menulis Teks Laporan Hasil Observasi yang Bermuatan Kearifan Lokal untuk Peserta Didik Kelas X SMA". Tesis. Program Pascasarjana Unnes.

Sitepu. 2015. Penulisan Buku Teks Pelajaran. Bandung: PT Remaja Rosdakarya.
Sua, A. T. 2018. "Bentuk, Fungsi, dan Nilai Ungkapan Bugis Masyarakat Bone”. (Disertasi). Program Pascasarjana, Universitas Negeri Makassar.

Subair, M. 2017. "Ekspresi Literasi Petuah Bijak pada MAN 1 Bone dan MAS Al-Junaediyah Biru Bone". Al-Qalam, 23(2), 370--383.

Sugiyono. 2016. Metode Penelitian \& Pengembangan (Research and Development/RnD). Bandung: Alfabeta.

Suryana, dkk. 2014. "Pengembangan Bahan Ajar Cetak Menggunakan Model Hannafin \& Peck untuk Mata Pelajaran Rencana Anggaran Biaya." E-Journal Program Pascasarjana Universitas Pendidikan Ganesha, Volume, 4 2014.

Syamsudduha. 2014. "Dimensi Kewacanaan Pappaseng: Kajian Wacana Kritis”. (Disertasi). Program Pascasarjana, Universita Negeri Makassar. 